\title{
The effect of coarse to fine aggregate ratio on drying shrinkage of roller compacted concrete pavement in different curing conditions
}

\author{
${ }^{\oplus}$ M. Abbasi a, b ${ }^{\oplus}$ P. Shafigh ${ }^{b, c} \bowtie,{ }^{\oplus}$ M.R. Baharum ${ }^{\text {a,b }}$ \\ a. Department of Building Surveying, Faculty of Built Environment, University of Malaya, (Kuala Lumpur, Malaysia) \\ b. Center for Building, Construction \& Tropical Architecture (BuCTA), Faculty of Built Environment, University of Malaya, (Kuala \\ Lumpur, Malaysia) \\ c. Center for Transportation Research, Faculty of Engineering, University of Malaya, (Kuala Lumpur, Malaysia) \\ pshafigh@gmail.com
}

\begin{abstract}
Drying shrinkage is an inevitable phenomenon that leads to cracks and eventually remarkable volume changes in hardened concrete. In this study, the drying shrinkage strain behavior of roller compacted concrete pavements (RCCPs) in two different curing conditions was investigated. The variables of RCCPs were coarse to fine aggregate $(\mathrm{C} / \mathrm{F})$ ratios of $0.7,1,1.2$ and 1.5 in two cement dosages of $12 \%$ and $15 \%$. Vebe tests of the fresh RCCP as well as the compressive, splitting tensile and flexural tensile strengths of the hardened RCCPs were also performed. The test results indicate that by increasing cement content from $12 \%$ to $15 \%$, the drying shrinkage strain increased in both cured and non-cured conditions. Generally, the drying shrinkage strain was significantly increased when the $\mathrm{C} / \mathrm{F}$ ratio was lower than 1.0. It is highly recommended that $\mathrm{C} / \mathrm{F}$ aggregate ratio is used in the range of 1.0 to 1.2 in the mixture of RCCP.
\end{abstract}

KEY WORDS: Roller compacted concrete pavement; Drying shrinkage; Coarse to fine aggregate ratio; Cement content; Mechanical properties.

Citation/Citar como: Abbasi, M.; Shafigh, P.; Baharum, M.R. (2021) The effect of coarse to fine aggregate ratio on drying shrinkage of roller compacted concrete pavement in different curing conditions. Mater. Construcc. 71 [342], e246. https://doi. org/10.3989/mc.2021.03520.

RESUMEN: Efecto de la relación entre el árido grueso y el fino en retracción por secado de pavimentos de hormigón compactados con rodillo en diferentes condiciones de curado. La retracción por secado es un fenómeno inevitable que produce fisuras y eventualmente cambios de volumen notables en el hormigón endurecido. En este estudio se investigó el comportamiento de la tracción por retracción por secado de pavimentos de hormigón compactado con rodillo (HCR) en dos condiciones de curado diferentes. Las variables consideradas en estos pavimentos HCR fueron la relación entre el árido grueso y el fino (G/F), considerando valores de $0,7,1,1,2$ y 1,5, y la dosis de cemento, del $12 \%$ y del $15 \%$. También se realizaron ensayos Vebe del HCR fresco, así como ensayos de resistencia a la compresión, resistencia a la tracción indirecta y de flexión de los HCR endurecidos. Los resultados de los ensayos indican que al aumentar el contenido de cemento del $12 \%$ al 15\%, la tracción por retracción por secado aumentó tanto en condiciones de curado como de no curado. En general, la tracción por retracción por secado aumentó significativamente cuando la relación $\mathrm{G} / \mathrm{F}$ era inferior a 1,0. Se recomienda que la relación $\mathrm{G} / \mathrm{F}$ del árido esté comprendida en el rango de 1,0 a 1,2 en la mezcla de HCR para pavimentos.

PALABRAS CLAVE: Pavimento de hormigón compactado con rodillo; Retracción por secado; Relación entre árido grueso y fino; Contenido de cemento; Propiedades mecánicas.

Copyright: (C2021 CSIC. This is an open-access article distributed under the terms of the Creative Commons Attribution 4.0 International (CC BY 4.0) License. 


\section{INTRODUCTION}

Roller compacted concrete pavement (RCCP) provides a sustainable means of pavement construction, which follows the three sustainability pillars: economic, social and environmental (1). Compared with Portland cement concrete (PCC), properties such as no dowel or steel reinforcement, no finishing, rapid construction and quick access to service and high durability has made RCCP an interesting pavement material (1-3). The placement and compaction of RCCP is similar to asphalt pavement construction. The constituents used in RCCP are identical to PCC, but in different ratios. RCCP is a stiff concrete with no slump that has a lower water demand and cement dosage in comparison to PCC $(2,3)$. Therefore, RCCP is dryer and stiffer than PCC $(3,4)$. These characteristics of RCCP provide appropriate mechanical properties that lead to less drying shrinkage in its construction. Drying shrinkage is one of the significant causes of concrete deflections, which appear on the surface of pavements in the first few days after placement and eventually cause remarkable volume reduction. Most of the reduced volume in concrete is due to loss of water in capillary and gel pores $(5,6)$. Due to the restraint of the pavement above the foundation, the volume reduction would produce stress that can exceed the concrete tensile strength $(5,6)$.

Drying shrinkage is an inevitable phenomenon that eventually induces cracking in a concrete member. It is affected by many factors such as aggregate, cement, water, ambient conditions (temperature, humidity and wind velocity), curing conditions and geometry (5-7). In a half-century of RCCP establishment, a few researches were published about the value and the influential factors of drying shrinkage of RCCP. According to Khayat and Libre (8), the maximum drying shrinkage of RCCP is between 400 and 500 microstrain. However, Pittman and Ragan (9) reported that in RCCP, using proper mix proportions, water to cement ratios and well-graded aggregates caused a lower drying shrinkage deformation with an average of 150 microstrain at 28 days. Gholami and Modarres (10) reported that the drying shrinkage value of RCCP is around 150 microstrain at 90 days while Jingfu et al. (11) revealed that the 90 days drying shrinkage of RCCP is near to 200 microstrain. It should be noted that values were reported in specific mix proportions and ambient conditions. Furthermore, in these researches, the effect of aggregate in RCCP has not been investigated comprehensively and some properties of RCCP were neglected, such as workability and mechanical properties.

The principal variables of drying shrinkage in concrete are aggregate volume and water content (5). The aggregate consumption in RCCP is more than PCC while aggregate usage in RCCP is $75-85 \%$ of the total volume, which is higher than $60-75 \%$ in PCC (3). Khayat and Libre (8) reported that by increasing the volume of aggregate, the water to cement ratio has less effect on drying shrinkage. It was revealed that the mechanical properties of concrete are strongly influenced by aggregate content. Hashemi et al. (12) reported that the coarse to fine aggregate ratio has a significant effect on the mechanical properties of RCCP. Furthermore, the maximum size of aggregate in concrete affects the mechanical properties and drying shrinkage of concrete (13). In addition, it is admitted that by increasing aggregate content, drying shrinkage decreases due to aggregate restraint (13-16). Therefore, the role of aggregate is substantial on the drying shrinkage of RCCP.

Although there are some studies on the influence of aggregate on the drying shrinkage of concrete, there is a lack of comprehensive studies on the influence of aggregate and coarse to fine aggregate ratio on the drying shrinkage of RCCP. Furthermore, limited data about the behavior of drying shrinkage of RCCP makes it essential to have a comprehensive investigation on it. Therefore, in this study the drying shrinkage of RCCP was investigated at different coarse to fine aggregate ratios. For this purpose, the drying shrinkage of RCCP in the short and long term, based on different coarse to fine aggregate ratios, was determined. In addition, hardened properties such as compressive, splitting tensile, flexural strengths and Vebe time test were investigated.

\section{EXPERIMENTAL DESIGN}

\subsection{Materials}

The grading curve of the combined coarse and fine aggregate was within Portland Cement Association (PCA) standard limits (17), as shown in Figure 1. The crushed granite as a coarse aggregate was used with a maximum nominal size of $12 \mathrm{~mm}$ with SSD, specific gravity of 2.62 and $24 \mathrm{~h}$ water absorption of $0.6 \%$. Low fines content sand was mined locally with fineness modulus, saturated surface-dry (SSD) specific gravity and $24 \mathrm{~h}$ water absorption of 2.8 , 2.55 and $1.5 \%$, respectively.

Ordinary Portland cement with a $48 \mathrm{MPa}$ compressive strength at 28 days was used. Specific gravity and specific surface area were 3.14 and 3510 $\mathrm{cm} 2 / \mathrm{g}$, respectively.

\subsection{Mix proportions}

The mix proportions that are adopted in this research are shown in Table 1. Four different coarse to fine aggregate ratios including $0.7,1,1.2$ and 1.5 in two cement dosages of $12 \%\left(269 \mathrm{~kg} / \mathrm{m}^{3}\right)$ and $15 \%$ $\left(332 \mathrm{~kg} / \mathrm{m}^{3}\right)$ by mass of total dry solid were applied. 


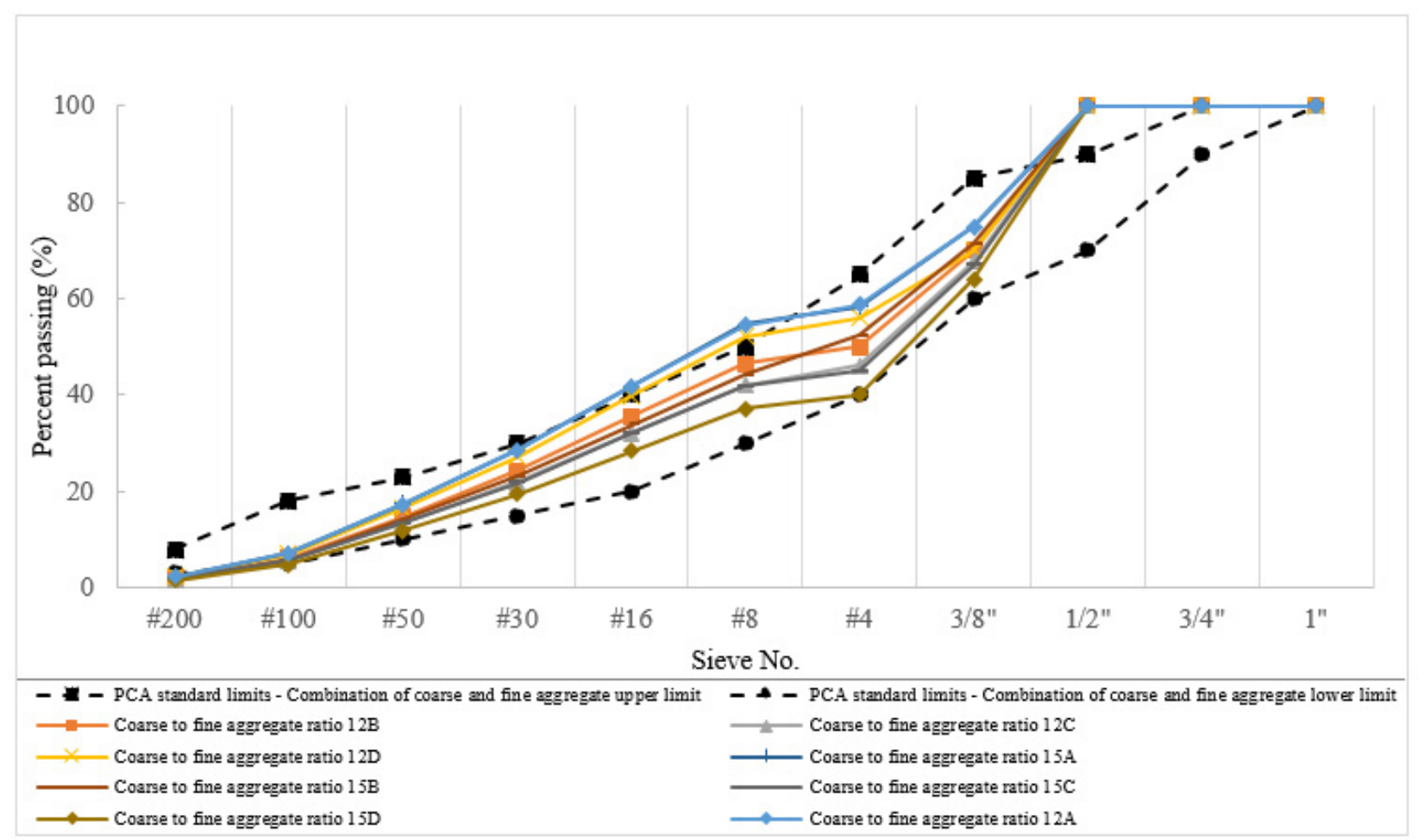

FIGURE 1. Sieve analysis of combination of coarse and fine aggregate in comparison with PCA standard limits.

The freshly mixed concretes were compacted in cylindrical molds using an electric vibrating hammer according to ASTM C 1435 (18). In addition, prism molds were used for the flexural tensile strength test. An electric vibrating hammer was used to prepare the prism specimens, which was equipped with a shaft and rectangular plate. Casting for prism specimens was fulfilled in three layers, and while the compaction of each layer was performed, observation of mortar formation on the top surface was carried out. Designation of the RCCP mixes was performed in accordance with the soil compaction concept of the relevant standards ASTM D1557 (19).

\subsection{Testing set-up and procedures}

The laboratory testing program was aimed at measuring the properties of RCCP in terms of workability, strengths and drying shrinkage strain. A modified Vebe test was employed to determine the consistency of RCCP. The hardened properties of concretes were

TABLE 1. Mix proportions of concretes, 28-day compressive strength and Vebe time.

\begin{tabular}{|c|c|c|c|c|c|c|c|c|}
\hline \multirow{2}{*}{ Mix ID } & \multicolumn{2}{|c|}{ Cement } & \multirow{2}{*}{$\begin{array}{l}\text { Water } \\
\left(\mathrm{kg} / \mathrm{m}^{3}\right)\end{array}$} & \multirow{2}{*}{$\begin{array}{c}\text { Coarse aggregate } \\
\left(\mathrm{Kg} / \mathrm{m}^{3}\right)\end{array}$} & \multirow{2}{*}{$\begin{array}{l}\text { Fine aggregate } \\
\qquad\left(\mathrm{Kg} / \mathrm{m}^{3}\right)\end{array}$} & \multirow{2}{*}{$\begin{array}{c}\text { Coarse to Fine } \\
\text { aggregate ratio }\end{array}$} & \multirow{2}{*}{$\begin{array}{c}\text { 28-day } \\
\text { Compressive } \\
\text { strength (MPa) }\end{array}$} & \multirow{2}{*}{ Vebe time (s) } \\
\hline & $\%$ & $\mathrm{Kg} / \mathrm{m}^{3}$ & & & & & & \\
\hline $12 \mathrm{~A}$ & \multirow{4}{*}{$12 \%$} & \multirow{4}{*}{269} & \multirow{4}{*}{108} & 812 & 1161 & 0.7 & 36 & 22 \\
\hline $12 \mathrm{~B}$ & & & & 986 & 986 & 1 & 42 & 25 \\
\hline $12 \mathrm{C}$ & & & & 1076 & 897 & 1.2 & 47 & 28 \\
\hline $12 \mathrm{D}$ & & & & 1184 & 798 & 1.5 & 47 & 33 \\
\hline $15 \mathrm{~A}$ & \multirow{4}{*}{$15 \%$} & \multirow{4}{*}{332} & \multirow{4}{*}{133} & 776 & 1108 & 0.7 & 42 & 15 \\
\hline $15 \mathrm{~B}$ & & & & 942 & 942 & 1 & 50 & 18 \\
\hline $15 \mathrm{C}$ & & & & 1028 & 857 & 1.2 & 51 & 20 \\
\hline $15 \mathrm{D}$ & & & & 1131 & 754 & 1.5 & 44 & 24 \\
\hline
\end{tabular}


measured by compressive strength, splitting tensile strength and flexural tensile strength tests at 28 days. Drying shrinkage strain of RCCP was measured by a demountable mechanical strain gauge (DEMEC).

\subsubsection{Drying shrinkage}

To measure drying shrinkage strain, six specimens with $100 \times 100 \times 300 \mathrm{~mm}$ dimensions for each mix were prepared and then divided into two groups: cured and non-cured. Three non-cured specimens were measured immediately after demolding and three cured specimens were cured in lime-saturated water for 7 days and were measured when taken out from the water. Both groups were measured every day for the first 7 days, and then every 7 days for 90 days according to ASTM C157 (20). The testing apparatus was a DEMEC with an accuracy of 0.5 microstrain (Figure 2). The average of six readings obtained as the drying shrinkage strain for each age. The specimens were kept in the laboratory, which was an uncontrolled room and had a temperature of $30 \pm 2^{\circ} \mathrm{C}$ and $70 \pm 5 \%$ relative humidity.

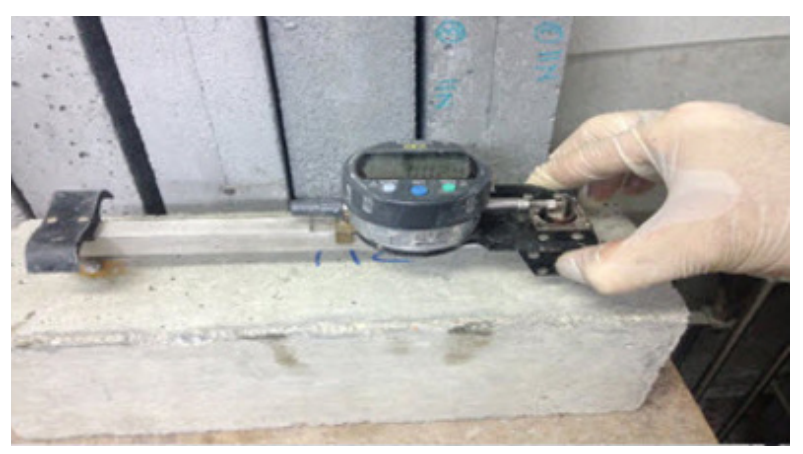

FIGURE 2. Drying shrinkage apparatus.

\subsubsection{Mechanical properties}

The compressive strength and splitting tensile strength tests were performed according to ASTM C39 (21) and ASTM C496 (22), respectively. Compressive strength testing was fulfilled on cylinder specimens of $100 \times 200 \mathrm{~mm}$ dimensions at 7 and 28 days whereas the splitting tensile strength tests, which had the same specimen dimensions, were accomplished at 28 days. On the other hand, the flexural tensile strength test was performed on $100 \times 100 \times 500 \mathrm{~mm}$ prism specimens according to ASTM C78 (23).

\subsubsection{Vebe test}

According to ASTM C1170 (24), a modified Vebe test was performed to attain the workability of each mix proportion. Due to the stiffness of RCC mixes, its workability and compaction possibility is very important.

\section{RESULTS AND DISCUSSION}

\subsection{Fresh properties}

The Vebe time and density for all RCCPs are presented in Table 1. There was no segregation in all concrete mixtures during mixing, placement and compaction. In other words, sufficient workability was seen for all RCCPs. Sufficient workability is a critical parameter for full compaction, uniform density, correct bonding with the last layer and also for the tolerance of compaction equipment (25). As can be seen in Table 1, the results show that the Vebe time decremented in cement dosage from $12 \%$ to $15 \%$ and incremented in coarse to fine aggregate ratio. Increasing cement dosage resulted in higher paste volume and lower Vebe time, which caused RCCP to have better compaction and finish (26). On the other hand, increasing the coarse to fine aggregate ratio from 0.7 to 1.5 with $12 \%$ and $15 \%$ cement increased the Vebe time by $50 \%$ and $60 \%$, respectively. Hashemi et al. (12) reported that incrementing the coarse to fine ratio in RCCP between 0.6 and 1.8 incremented the Vebe time up to three times. However, increasing cement from $12 \%$ to $15 \%$ decreased the Vebe time $28 \%$. According to Vahedifard et al. (27), incrementing the cement dosage in RCCP between $12 \%$ and $15 \%$ resulted in Vebe time reduction of $10 \%$.

\subsection{Mechanical properties}

Figure 3 to Figure 5 present the relationships between compressive, splitting tensile and flexural strengths and coarse to fine aggregate ratio for RCCPs consisting of $12 \%$ and $15 \%$ cement dosages at 28 -day age. RCCPs with $12 \%$ cement exhibited an increment for the strengths of compressive, splitting tensile and flexural tensile about 30\%, 15\% and $32 \%$ when the coarse to fine aggregate ratio was changed from 0.7 to 1.2 , respectively. Afterward, those strengths decreased around $0 \%, 15 \%$ and $4 \%$ when the coarse to fine aggregate ratio was changed from 1.2 to 1.5 , respectively. In the second group, where the cement content was $15 \%$, similar trends were monitored. The compressive and splitting tensile strengths as well as the flexural tensile strength incremented by about $21 \%, 17 \%$ and $19 \%$ with coarse to fine ratios of $0.7,1$ and 1.2 , respectively. Subsequently, those strengths decreased by around $14 \%, 7 \%$ and $9 \%$ when the coarse to fine ratio incremented from 1.2 to 1.5 , respectively. 
The effect of coarse to fine aggregate ratio on drying shrinkage of roller compacted concrete pavement in different curing conditions $\bullet 5$

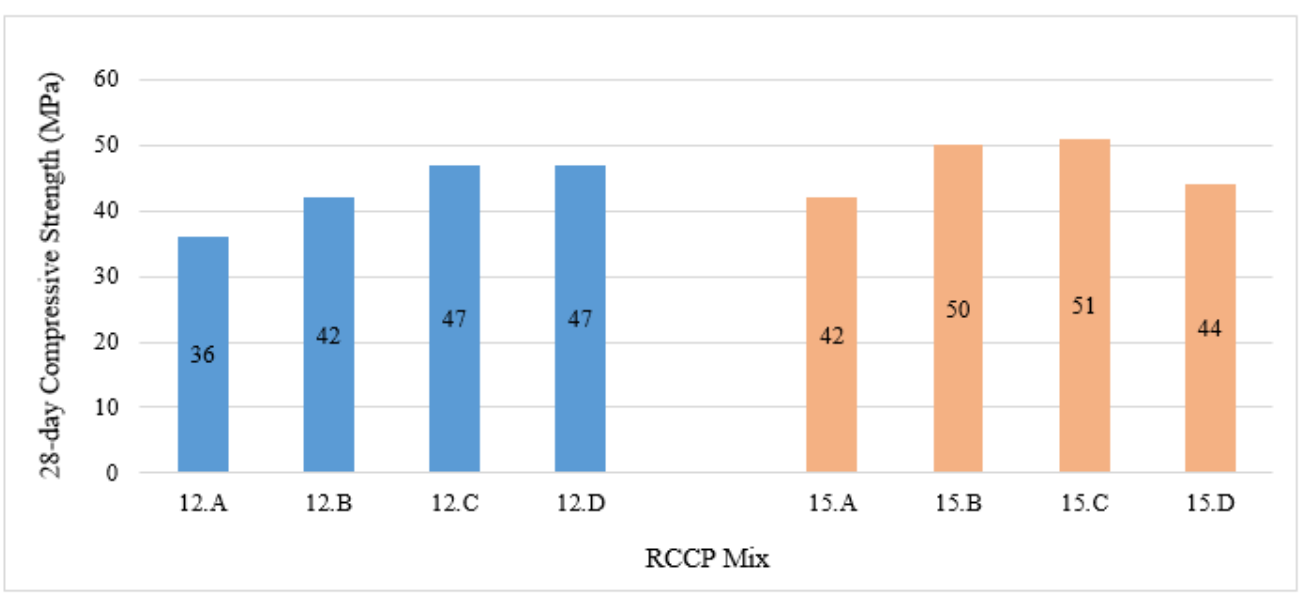

FIGURE 3. The 28-day compressive strength of RCCP mixes.

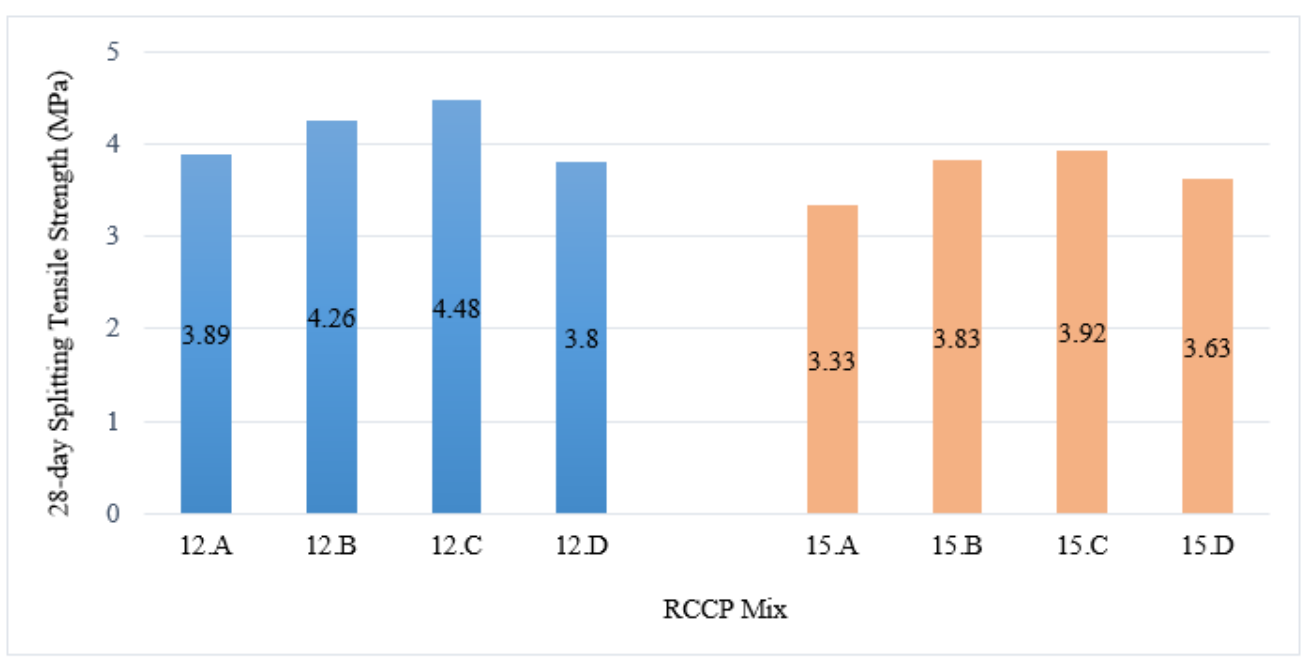

FIGURE 4. The 28-day splitting tensile strength of RCCP mixes.

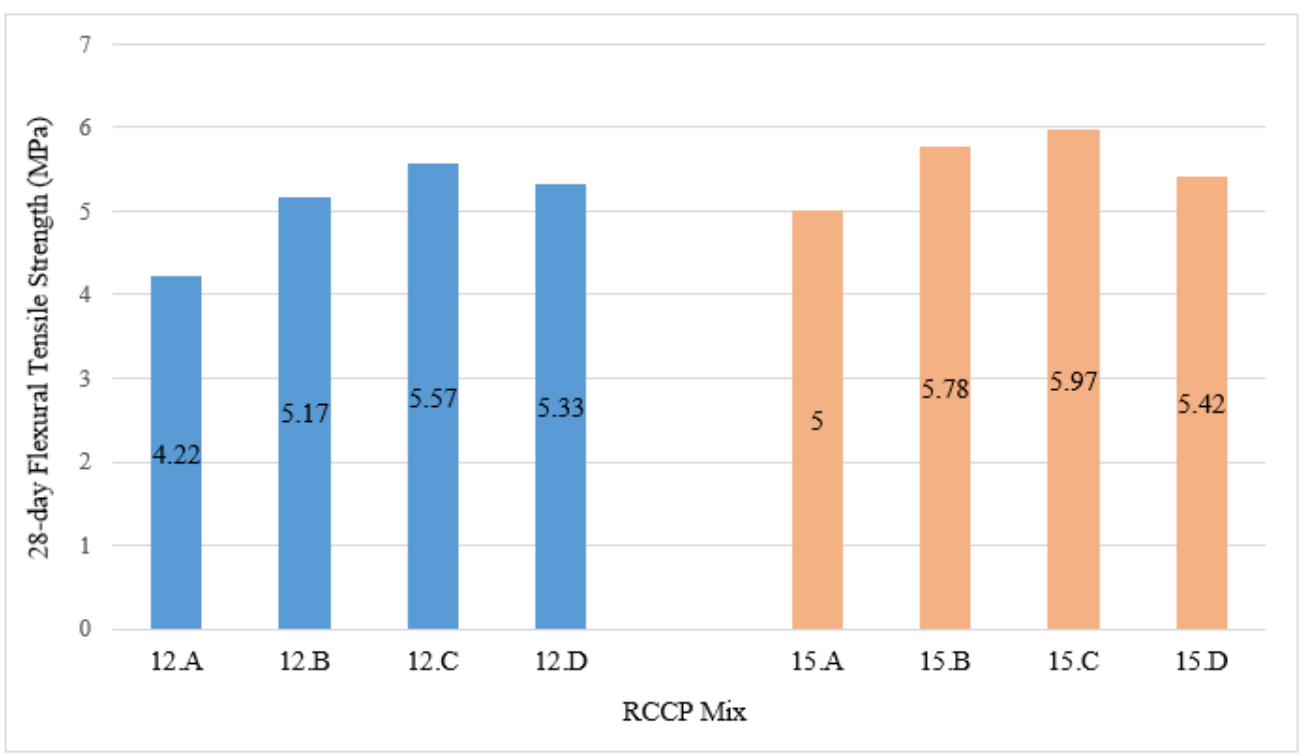

Figure 5. The 28-day flexural tensile strength of RCCP mixes. 
As can be seen for all RCCPs with two cement dosages, the strengths of compressive, splitting tensile and flexural tensile reached the peak of the strengths at a coarse to fine aggregate ratio of 1.2. The reason could be due to higher pack-density and a more dense structure of RCCP with a coarse to fine aggregate ratio of 1.2.

ASTMC 330-89 specified that the cylinder compressive strength must be at least $17 \mathrm{MPa}$ at 28 days (28). PCA demonstrated that the compressive strength is almost the same for both RCCP and PCC, which is generally around $28-41 \mathrm{MPa}$. In addition, the British Department for Transport (29) determined that the 28-day splitting tensile strength of a concrete that is used in road construction should not be less than 1.8. Moreover, the British Airports Authority (BAA) noted that the minimum 28-day flexural tensile strength of a concrete must be $4 \mathrm{MPa}$ (29). The current test results determine that all RCCPs are above requirements.

\subsection{Drying shrinkage}

The average drying shrinkage strain development of RCCP specimens over 90 days in cured and non-cured conditions was determined. Therefore, the role of the coarse to fine aggregate ratio on the drying shrinkage of RCCPs was compared and investigated in both conditions. Furthermore, the drying shrinkage values were compared with previous studies.

\subsubsection{Non-cured condition}

Figure 6 shows the effect of the coarse to fine aggregate ratio (from 0.7 to 1.5 ) on the drying shrinkage strain values of RCCPs with $12 \%$ and $15 \%$ cement content. As can be seen in Figure 6 , the drying shrinkage of RCCPs within the first 28 days significantly increased. As expected, the rate of increasing of the shrinkage strain was reduced by time. This rate was much less after the age of 56 days. It is also obvious in Figure 6 that RCCPs with $15 \%$ cement have higher drying shrinkage strain at all early and later ages. Compared to the drying shrinkage values at 90 days, around $40 \%$ of the drying shrinkage strain occurred at 7 days after drying, while it was around $70 \%$ at 28 days. According to Troxell et al. (30), near to $25 \%$ of the 10 -year drying shrinkage was realized at 14 days and 50 to $60 \%$ at 90 days and below $80 \%$ in 1 year. Pittman reported that the 28-day drying shrinkage of concrete might occur with an average of $40 \%$ of the 20 years shrinkage (4-9).

The mix of $12 \mathrm{C}$ with $12 \%$ cement content and a coarse to fine aggregate ratio of 1.2 showed the lowest drying shrinkage strain, whereas the mix of $15 \mathrm{~A}$ with $15 \%$ cement content and a coarse to fine aggregate ratio of 0.7 exhibited the highest drying shrinkage strain in most of the periods during the 90 days.

The mix of $12 \mathrm{C}$ attained the lowest drying shrinkage strain values after 28 days with 215,260 and 295 microstrain at 28, 56 and 90 days, respectively. However, at the early ages (before 28 days), the drying shrinkage strain of mix $12 \mathrm{C}$ was almost $25 \%$ higher than $12 \mathrm{~A}$ (with $12 \%$ cement content and $\mathrm{C} / \mathrm{F}$ ratio of 0.7 ). The mix of $12 \mathrm{~A}$ had the lowest drying shrinkage strain at the early ages until 21 days with 98, 135 and 190 microstrain at 7, 14 and 21 days, respectively. As with $12 \mathrm{C}$, similar trends were observed for $12 \mathrm{~A}, 12 \mathrm{~B}, 12 \mathrm{D}$ from 28 days up to 90 days, while the shrinkage values for these mixes were $10 \%$ higher than mix $12 \mathrm{C}$ on average.

Therefore, it can be concluded that mix 12C might have the lowest drying shrinkage strain in the long term. Pittman and Ragan (9) reported that an RCC mix with mid-range coarse to fine ratio (around 1) and optimum moisture content would have the lowest drying shrinkage strain at 28 days. Zhang et al. (31) demonstrated that increasing coarse aggregate content in concrete reduces the shrinkage strain. They also reported that the effect of coarse aggregate on drying shrinkage is considerably higher than autogenous shrinkage. Adam et al. (32) studied the influence of coarse aggregate on drying shrinkage of concrete. They reported that using more aggregates caused cement paste to have a lower drying shrinkage due to elastic deformation of the aggregate, which leads to restraining of the drying shrinkage of cement paste. However, Pittman and Ragan (9) reported that using higher coarse aggregate content along with higher water content in RCCP might result in higher drying shrinkage. Mehta and Monteiro (33) revealed that concrete with higher coarse aggregate content leads to higher elasticity in concrete. According to Neville (34), higher elastic modulus in concrete results in lower drying shrinkage. Neville (34) also reported that aggregate is a significant factor affecting shrinkage in concrete that restrains the shrinkage. The following equation obviously shows the importance of aggregate volume (Equation [1]):

$$
\mathrm{S}_{\mathrm{c}}=\mathrm{S}_{\mathrm{p}}(1-\mathrm{a})^{\mathrm{n}}
$$

Where $S_{c}$ is the shrinkage of concrete, $S_{p}$ is the shrinkage of the cement paste, $a$ is the volume fraction of aggregate and $\mathrm{n}$ is a constant depending on the elasticity of aggregate and varies between 1.2 and 1.7 .

On the other hand, incrementing the cement dosage from $12 \%$ to $15 \%$ led to drying shrinkage increment. The mix of $15 \mathrm{~A}$ (with $15 \%$ cement content and $\mathrm{C} / \mathrm{F}$ of 0.7 ) attained the highest drying shrinkage among all non-cured RCCPs, while the 


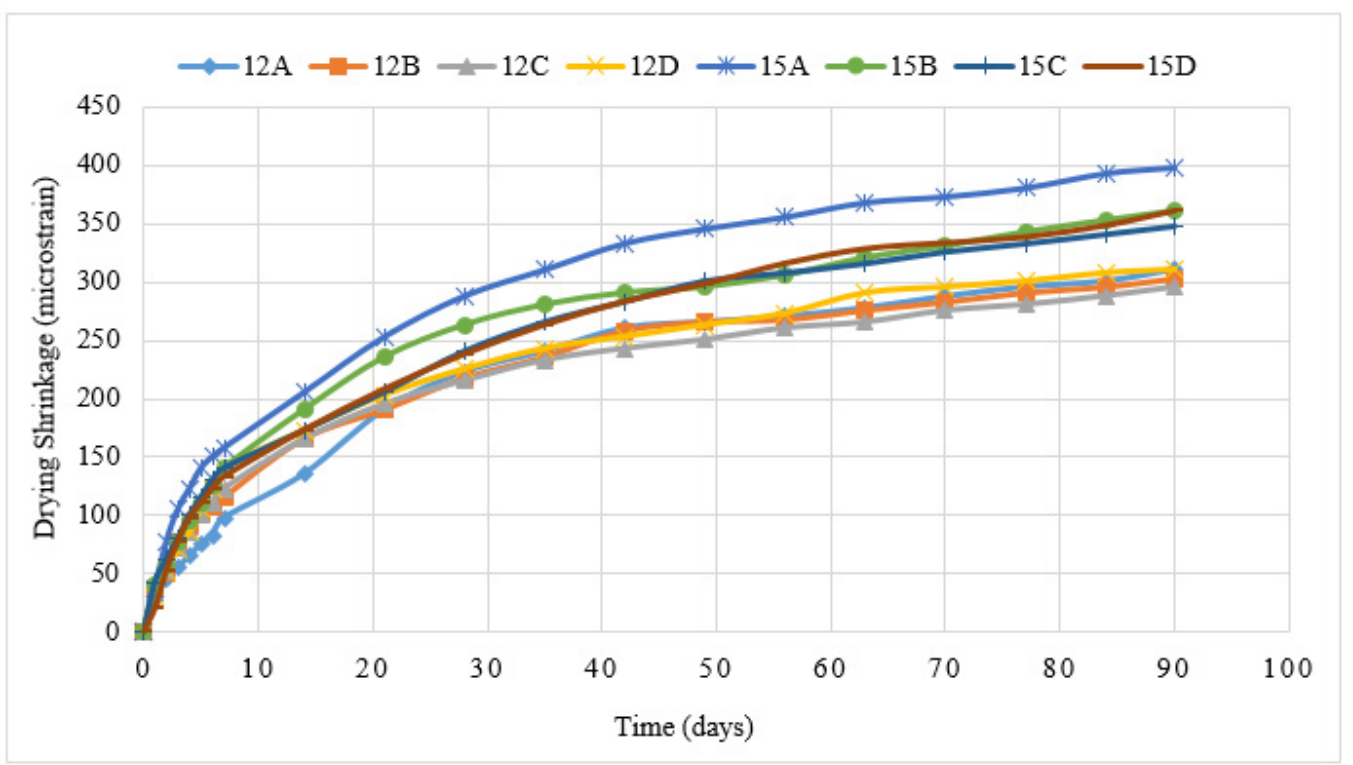

FIGURE 6. Drying shrinkage development of RCCP mixes for non-cured condition.

drying shrinkage values were 288,335 and 398 microstrain at 28,56 and 90 days, respectively. Thus, $\mathrm{RCCP}$ with $0.7 \mathrm{C} / \mathrm{F}$ and $15 \%$ ratio would lead to higher drying shrinkage strain. The RCCP mixes of $15 \mathrm{~B}, 15 \mathrm{C}$ and $15 \mathrm{D}$ had similar trends in most of the periods with an average drying shrinkage of 350 microstrain at 90 days. However, the average drying shrinkage values for the mix of $15 \mathrm{~B}$ was almost $10 \%$ higher than $15 \mathrm{C}$ and $15 \mathrm{D}$ from 7 to 28 days. Similar to RCCPs with $12 \%$ cement content, the drying shrinkage values had a sharp increment up until 56 days, and afterwards the trends were almost constant up until 90 days.

In total, by incrementing the cement dosage from $12 \%$ to $15 \%$, the drying shrinkage of RCCPs had almost $20 \%$ increment on average. The drying shrinkage strain had a remarkable increment of $12 \%$ when the coarse to fine ratio was lower than 1.0 for RCCPs with $15 \%$ cement content. However, for RCCPs with $12 \%$, no significant changes were shown. Therefore, it can be concluded that the RCCPs with $15 \%$ cement would tend to exhibit higher drying shrinkage. According to Pittman and Ragan (9), using higher water content with finer aggregate might induce higher drying shrinkage. Gholami and Modarres (10) studied the drying shrinkage of superplasticized RCCP and reported that by adding more water content, the drying shrinkage of RCCP at the early ages increased significantly.

Jingfu et al. (11) carried out an investigation on rubberized RCCP and demonstrated that the shrinkage of concrete initiated from cement paste and aggregate exhibits as a shrinkage restrainer. Carlson (13) revealed that cement paste, which is not restrained by aggregate, shrinks 5 to 15 times more than PCC. Wongkeo et al. (35) demonstrated that cement paste in concrete is usually where drying shrinkage originates. This is in accordance with Mehta and Monteiro (33). Bogas et al. (36) reported that using a higher volume of water induces higher vapor, which finally results in a considerable volume change in concrete. They also demonstrated that when the water and cement content (paste volume) is higher, the rigidity of concrete might be lower. According to Aslam et al. (37), the shrinkage of concrete is highly affected by cement paste due to cement contraction, and the higher water content in concrete eventually yields considerable volume changes.

\subsubsection{Cured condition}

Figure 7 indicates the development of drying shrinkage strain of RCCPs for the cured condition. All the specimens were measured immediately after 7 days' moist curing for the first time up until 90 days. As is clearly shown, similar to the noncured condition, drying shrinkage strain increased by increasing cement content from $12 \%$ to $15 \%$ while significant increase was monitored in drying shrinkage strain when the coarse to fine ratio was lower than 1 . The drying shrinkage strain decreased when the coarse to fine aggregate ratio decreased to below 1 , with an average of $21 \%$ and $27 \%$ for $12 \%$ and $15 \%$ cement dosage, respectively.

As the non-cured condition, the mix of $12 \mathrm{C}$ had the lowest and the mix of $15 \mathrm{~A}$ had the highest drying shrinkage strain in the long term, respectively. The drying shrinkage values for the mix of $12 \mathrm{C}$ were 198,242 and 310 microstrain at 28,56 and 90 
days, respectively; while, it was 302, 378 and 427 for $15 \mathrm{~A}$, respectively.

The mix of 12A had the lowest drying shrinkage strain until 20 days with 188 microstrain while after 20 days the shrinkage values had a significant increase up to 90 days and reached a peak of 390 microstrain at 90 days. The trend and values for the mixes of $12 \mathrm{~B}$ and $12 \mathrm{D}$ were very close to each other, and the ultimate drying shrinkage strain was 330 microstrain on average. Thus, the mix of $12 \mathrm{C}$ tends to have the least drying shrinkage strain. This might be due to the higher aggregate content, more coarse aggregate than fine aggregate and higher elasticity in this mix, which exhibited as a shrinkage restrainer in RCCP (11-13), (32-34). Kovler and Jensen (38) studied aggregate replacement in lightweight aggregate and demonstrated that by increasing the volume of aggregate replacements, the fraction of paste would be increased.

On the other hand, RCCPs with $15 \%$ cement content had higher drying shrinkage strain. The mix of $15 \mathrm{~A}$ attained the highest drying shrinkage values during almost every period, and the shrinkage values were 302,378 and 427 microstrain at 28, 56 and 90 days, respectively. Therefore, the RCCP that has $15 \%$ cement content with a coarse to fine ratio of 0.7 would have higher drying shrinkage strain.

For the mixes $15 \mathrm{~B}, 15 \mathrm{C}$ and $15 \mathrm{D}$, the shrinkage values were very close to each other, and the ultimate drying shrinkage strain was 335 microstrain on average. Therefore, mix $15 \mathrm{~A}$ would attain higher drying shrinkage strain. This might be for two major reasons. The first reason is higher usage of fine aggregate content, which led to lower elasticity in concrete and higher drying shrinkage strain
$(34,35)$. The second reason is higher paste volume, which resulted in higher shrinkage (35-37).

In total, as with the non-cured condition, the increase of water and cement content showed an increment in drying shrinkage with an average of $6 \%$. This is because of higher paste volume (conversely less aggregate content). Neville (5) revealed that two significant factors that affect drying shrinkage in concrete are aggregate content and water content (initial moisture) and reported that the loss of adsorbed water yields most of the changes in concrete volume, while loss of free water derives little or no shrinkage. Basma and Jawad (39) reported that the rate of water loss in concrete affects the drying shrinkage strain of concrete. Day et al. (40) revealed that the drying shrinkage of concrete is more influenced by adding more water when concrete is in its fresh state. Aslam et al. (37) demonstrated that by decreasing the water content in concrete, the drying shrinkage of the concrete will be decreased more.

In conclusion, the average drying shrinkage strain in non-cured and cured conditions were around 330 and 350 microstrain at 90 days, respectively. According to the literature, the drying shrinkage of RCCP is less than PCC with a maximum of 400-500 microstrain (8) while the drying shrinkage of normal concrete is reported to range between 200 and 1200 microstrain due to its ingredient and mix proportion (9).

However, the effect of curing could not be neglected. While curing contributed to attaining lower drying shrinkage at the early ages, for the long term, curing led to higher drying shrinkage strain. Aslam et al. (37) revealed that curing yields lower

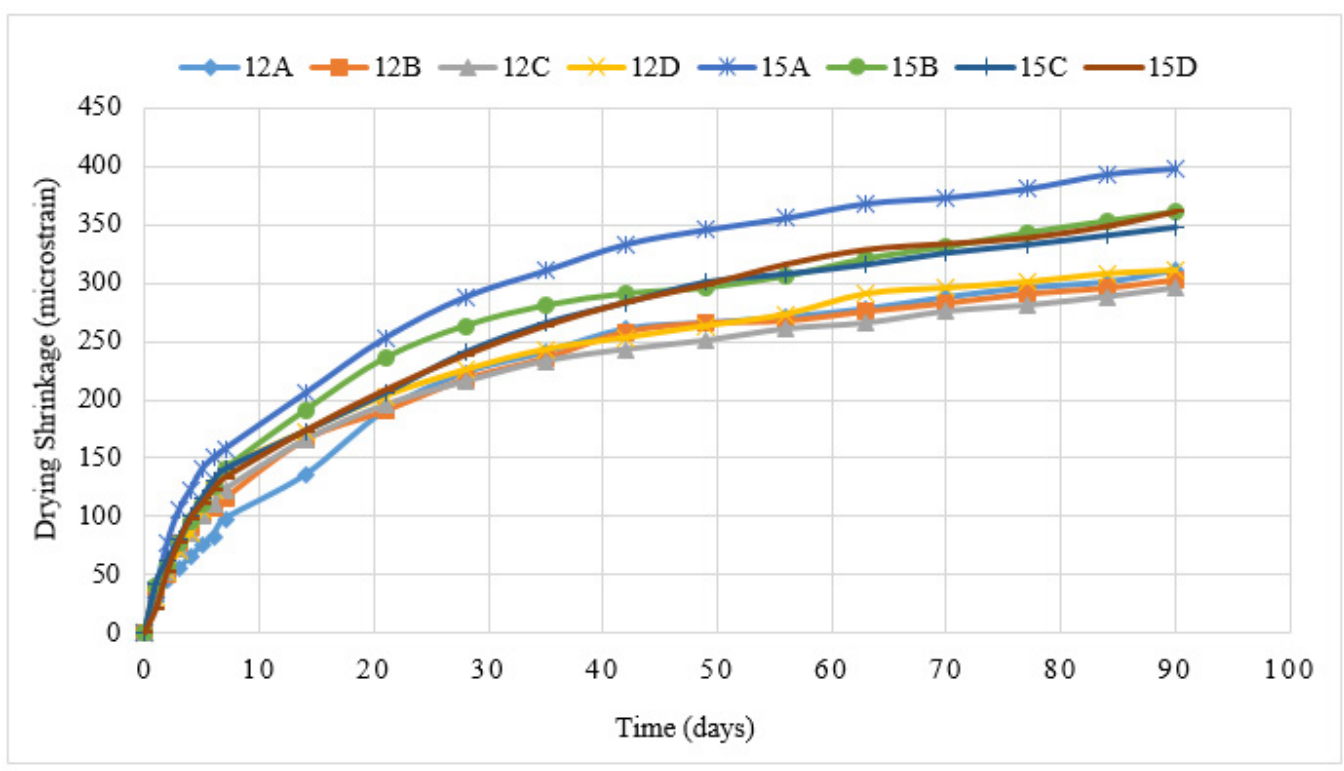

FIGURE 7. Drying shrinkage development of RCCP mixes for cured condition. 
drying shrinkage at the early ages. On the contrary, Carlson (13) reported that curing in concrete led to higher shrinkage. However, there is a necessity to carry out a comprehensive investigation on the curing effect on the drying shrinkage of RCCP.

In this study, it was found that RCCP with $1.2 \mathrm{C} / \mathrm{F}$ ratio and $12 \%$ cement content not only achieved the least drying shrinkage strain in both cured and noncured conditions, but also, with regard to the results for fresh and mechanical properties (section $3.1 \&$ 3.2 ), the mix of $12 \mathrm{C}$ had the appropriate properties. This is in accordance with Hashemi et al. (12), who recommended a mixture with $12 \%$ cement content and a coarse to fine aggregate ratio of 1.2 to achieve a workable, high-strength and durable RCCP.

However, it is obvious that the other parameters that might affect the drying shrinkage of RCCP need to be investigated comprehensively.

\subsubsection{Comparison with prediction models}

Table 2 shows the list of models and related equations that were used in this study for predicting the ultimate drying shrinkage strain of RCCPs. Three prediction models were ACI 209.2 R-08, Bazant-Baweja B3 and GL2000 (41).

The ultimate drying shrinkage for Bazant-Baweja B3 and GL2000 models is provided by the related equations in Table 2 while the ACI 209.2 $\mathrm{R}-08$ prediction model required the ultimate drying shrinkage to achieve the drying shrinkage development during the time. With regard to the literature, Neville reported that the 28-day drying shrinkage is almost $40 \%$ of the 20 -year shrinkage. Therefore, the 28-day drying shrinkage strain was used to compare with the data carried out in this study.
Figure 8 and Figure 9 show the comparison of drying shrinkage strain in this study among the prediction models, which are calculated by the average in both cured and non-cured conditions at 1 , $7,14,28,56$ and 90 days.

As is clear, in both curing conditions the drying shrinkage strain provided by both ACI 209.2 R-08 and Bazant-Baweja B3 is lower than the measured shrinkage in this study by an average of $46 \%$ and $21 \%$, respectively, while the average drying shrinkage strain that is provided by GL2000 in both curing conditions is $50 \%$ higher than the measured RCCPs on average. In total, the Bazant-Baweja B3 and GL2000 models had the lowest and highest difference with the measured drying shrinkage, respectively. Furthermore, Bazant-Baweja B3 gave the best prediction for drying shrinkage strain at the early ages with $17 \%$ and $19 \%$ difference with the measured RCCPs at 7 and 28 days, respectively.

\section{CONCLUSIONS}

This study was performed to investigate the effect of coarse to fine aggregate ratios on the drying shrinkage of roller compacted concrete pavement (RCCP) by providing eight mix proportions: four different coarse to fine aggregate ratios $(0.7,1,1.2$ and 1.5$)$ and two cement dosages $(12 \%$ and $15 \%$ of total dry solid mass). The drying shrinkage development was monitored in both cured and noncured conditions, and measurements commenced once the specimens were demolded for up to 90 days. In addition, the fresh and hardened properties of RCCPs were carried out. The study may have resulted in following conclusions:

TABLE 2. Drying shrinkage prediction models.

\begin{tabular}{|c|c|c|}
\hline Model name & Equations & Note \\
\hline ACI 209.2 R-08 (41) & $\varepsilon_{\text {sh }}\left(\mathrm{t}-\mathrm{t}_{\mathrm{c}}\right)=. \varepsilon_{\text {shu }}$ & $\begin{array}{l}\mathrm{t}-\mathrm{t}_{\mathrm{c}}: \text { duration of drying } \\
\alpha=1, \mathrm{f}=35\end{array}$ \\
\hline Bazant-Baweja B3 (41) & $\begin{array}{l}\varepsilon_{\mathrm{sh}}\left(\mathrm{t}-\mathrm{t}_{\mathrm{c}}\right)=-\varepsilon_{\mathrm{sh} \infty} \mathrm{k}_{\mathrm{h}} \mathrm{S}\left(\mathrm{t}-\mathrm{t}_{\mathrm{c}}\right) \\
\varepsilon_{\mathrm{sh} \infty}=-\varepsilon_{\mathrm{s} \infty} \\
\mathrm{E}_{\mathrm{cm} 607}=1.167 \mathrm{E}_{\mathrm{cm} 28} \\
\mathrm{E}_{\mathrm{cm} 28}=4734 \\
=\mathrm{E}_{\mathrm{cm} 28}( \\
\tau_{\mathrm{sh}}=0.085 \mathrm{t}_{\mathrm{c}}^{-0.08} \mathrm{f}_{\mathrm{cm} 28}-0.25\left[\left(2 \mathrm{k}_{\mathrm{s}}(\mathrm{V} / \mathrm{S})^{2}\right]\right. \\
\varepsilon_{\mathrm{s} \infty}=-\alpha_{1} \alpha_{2}\left(0.019 \mathrm{w}^{2.1} \mathrm{f}_{\left.\mathrm{cm} 28^{-0.28}+270\right) 10^{-6}}\right. \\
\mathrm{K}_{\mathrm{h}}=1-\mathrm{h}^{3} \\
\mathrm{~S}(\mathrm{t})=\tanh \end{array}$ & $\begin{array}{l}\text { V/S: specimen's volume-surface ratio }(21.428 \mathrm{~mm}) \\
\mathrm{t}_{\mathrm{c}}: \text { curing age when the drying shrinkage test starts (7 days) } \\
\mathrm{f}_{\mathrm{cm} 28}: 28 \text {-day cylinder compressive strength } \\
\alpha_{1}: \text { cement type constant }=1 \\
\alpha_{2}: \text { constant for curing condition (for cured and non-cured } \\
\text { condition } 1 \text { and } 1.2 \text { respectively) } \\
\mathrm{f}_{\mathrm{cm} 28}: 28 \text {-day compressive strength } \\
\text { w: water content } \\
\mathrm{h}: \text { relative humidity }(70 \%) \\
\mathrm{t}-\mathrm{t}_{\mathrm{c}}: \text { duration of drying }\end{array}$ \\
\hline GL2000 (Gardner 2004) (41) & $\begin{array}{l}\varepsilon_{\text {sh }}\left(\mathrm{t}-\mathrm{t}_{\mathrm{c}}\right)=\varepsilon_{\text {shu }} \beta(\mathrm{h}) \beta\left(\mathrm{t}-\mathrm{t}_{\mathrm{c}}\right) \\
\varepsilon_{\text {shu }}=900 \mathrm{k}()^{1 / 2} \times 10^{-6} \\
\beta(\mathrm{h})=1-1.18 \mathrm{~h}^{4} \\
\beta\left(\mathrm{t}-\mathrm{t}_{\mathrm{c}}\right)=\left[{ }^{1 / 2}\right.\end{array}$ & $\begin{array}{l}\mathrm{k}: \text { cement type function }=1 \\
\mathrm{f}_{\mathrm{cm} 28}: 28 \text {-day cylinder compressive strength } \\
\mathrm{h} \text { : relative humidity }(70 \%) \\
\mathrm{t}-\mathrm{t}_{\mathrm{c}} \text { : duration of drying } \\
\text { V/S: specimen's volume-surface ratio }(21.428 \mathrm{~mm})\end{array}$ \\
\hline
\end{tabular}




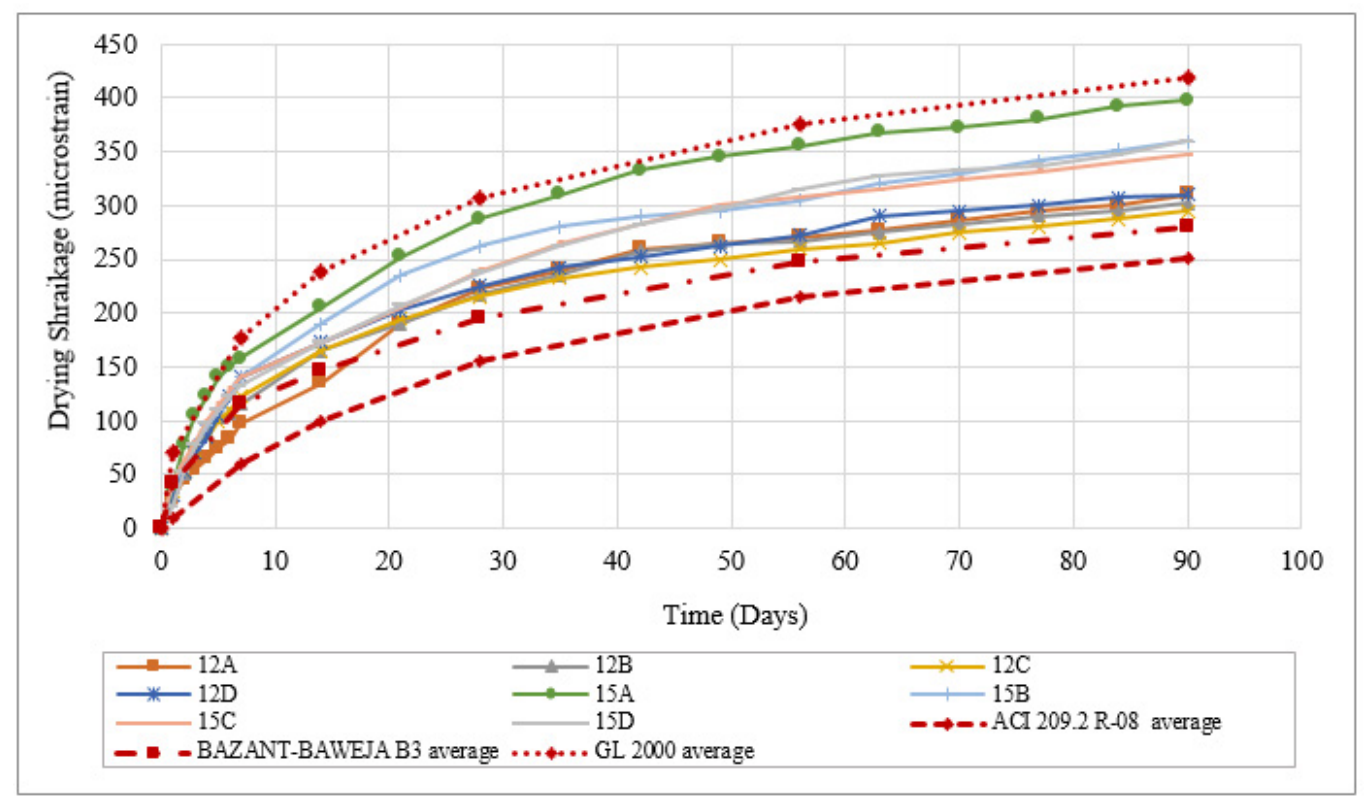

FIGURE 8. Comparison of drying shrinkage models to non-cured RCCP mixes.

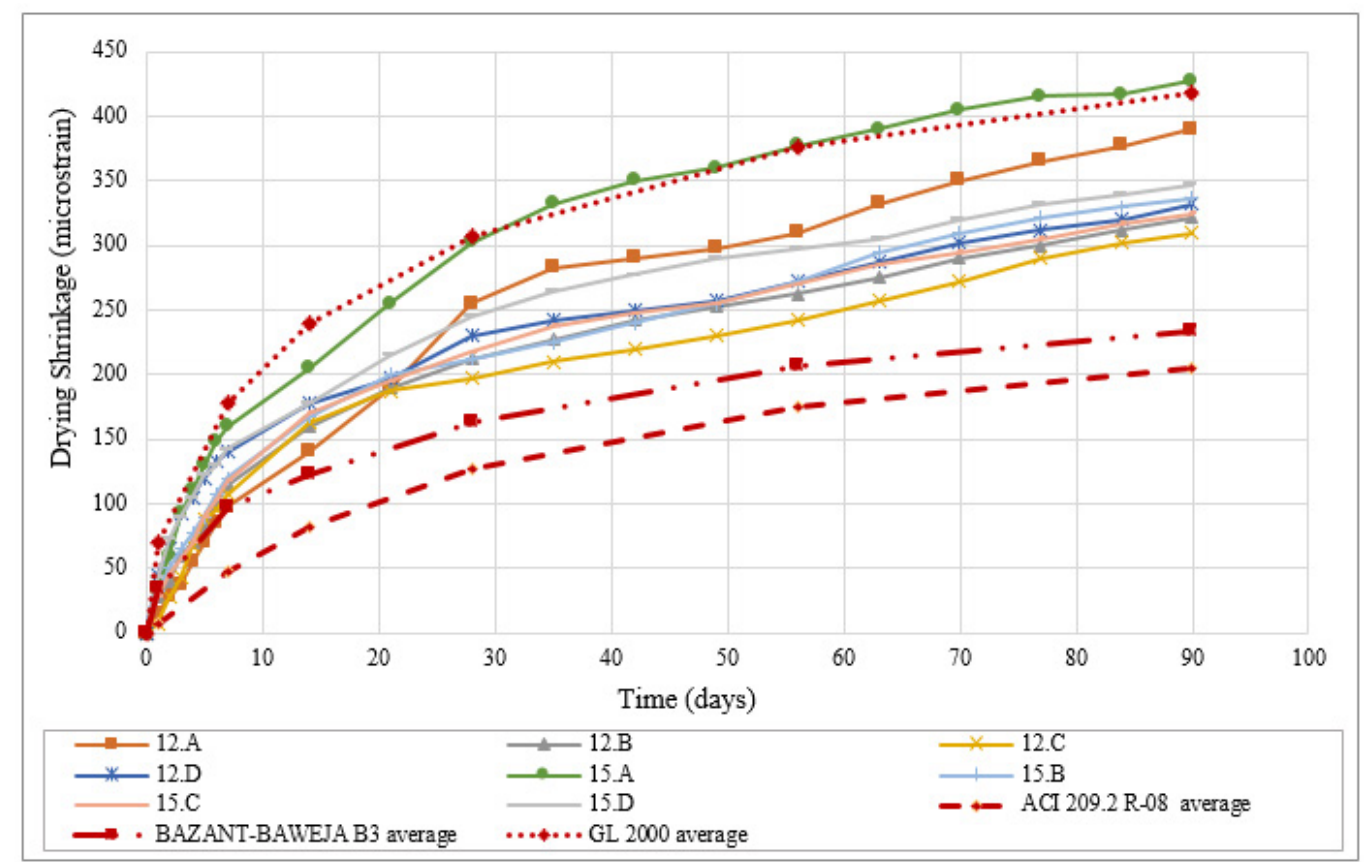

FIGURE 9. Comparison of drying shrinkage models to cured RCCP mixes.

Increasing the coarse to fine aggregate ratio from 0.7 to 1.5 for RCCPs, which contained $12 \%$ and $15 \%$ cement content, led to an increment in Vebe time values by $50 \%$ and $60 \%$, respectively.

Increasing the coarse to fine aggregate ratio from 0.7 to 1.2 led to increments in the strengths of compressive, splitting tensile and flexural tensile of about $21 \%, 17 \%$ and $19 \%$, respectively. However, by increasing the coarse to fine aggregate ratio from
1.2 to 1.5 , those strengths decreased by around $14 \%$, $7 \%$ and $9 \%$, respectively.

For both RCCPs with $12 \%$ and $15 \%$ cement contents, the compressive, splitting tensile and flexural tensile strengths reached the peak of the strengths at a coarse to fine aggregate ratio of 1.2 .

In non-cured condition, around $40 \%$ of the entire drying shrinkage strain occurred in the first 7 days after drying, while it was around $70 \%$ in the first 28 
days. In this condition, the highest and lowest drying shrinkage strain was recorded at 90 days with about 400 microstrain (mix 15A) and 300 microstrain (mix 12C), respectively. While, in cured condition, they were recorded as 430 microstrain (mix 15A) and 310 microstrain (mix 12C), respectively.

In both cured and non-cured conditions, the drying shrinkage strain increased by increasing the cement content from $12 \%$ to $15 \%$. In addition, a significant increase was monitored in the drying shrinkage strain when a coarse to fine aggregate ratio lower than 1.0 was used. Therefore, it is recommended to use more coarse aggregate than fine aggregate in the RCCP mixtures.

By considering test results of fresh and mechanical properties, it is recommended to use a coarse to fine aggregate ratio in the range of 1.0 to 1.2 in RCCP mixture.

Bazant-Baweja B3 had the best prediction for drying shrinkage strain of RCCPs compared to ACI 209.2 R-08 and GL2000.

\section{ACKNOWLEDGMENT}

This work was supported by the University of Malaya research grant (grant no. RF001F-2018).

\section{REFERENCES}

1. Van Dam, T.; Taylor, P.; Fick, G.; VanGeem, M.; Lorenz, E. (2012) Sustainable concrete pavements: a manual of practice. https://www.semanticscholar.org/paper/Sustainable-Concrete-Pavements\%3A-A-Manual-of-Dam-Taylor/773d1e391e13173dc27abffc74c5d186823d5c93.

2. Zollinger, D.G. (2016) Roller-Compacted Concrete Pavement: [techbrief] (No. FHWA-HIF-16-003). United States. Federal Highway Administration https://www.fhwa.dot.gov/ pavement/pub details.cfm?id=993.

3. Harrington, D.; Abdo, F.; Adaska, W.; Hazaree, C.V.; Ceylan, H.; Bektas, F. (2010) Guide for roller-compacted concrete pavements. https://lib.dr.iastate.edu/intrans reports/102/.

4. Pittman, D.W. (1989) The Effects of the Construction Process on Selected Fresh and Hardened Properties of Roller-Compacted Concrete (RCC) Pavements. Army engineer waterways experiment station. Vicksburg Ms Geotechnical Lab. https://apps.dtic.mil/sti/citations/ADA213735.

5. Neville, A.M. (1995) Properties of concrete (Vol. 4). London: Longman.

6. Cement Concrete and Aggregates Australia (2002) Drying Shrinkage of Cement and Concrete. https://www.ccaa.com. au/iMIS Prod.

7. Avram, C. (1981) Concrete Strength and Strains, Elsevier Scientific Pub. Co. (1981).

8. Khayat, K.H.; Libre, N.A. (2014) Roller compacted concrete: field evaluation and mixture optimization (No. NUTC R363). Missouri University of Science and Technology. Center for Transportation Infrastructure and Safety. https:// www.semanticscholar.org/paper/Roller-Compacted-Concrete \%3A-Field-Evaluation-and-Khayat-Libre/002baa236c54e20a58991d675089cf08233b7fdb.

9. Pittman, D.W.; Ragan, S.A. (1998) Drying shrinkage of roller-compacted concrete for pavement applications. Mater. Jour. 95 [1], 19-26. https://doi.org/10.14359/348.

10. Gholami, N.; Modarres, A. (2019) Shrinkage behaviour of superplasticised RCCP and its relationship with internal tem- perature. Inter. Pave. Engi. 20 [1], 12-23. https://doi.org/10.1 080/10298436.2016.1244438.

11. Jingfu, K.; Chuncui, H.; Zhenli, Z. (2009) Strength and shrinkage behaviors of roller-compacted concrete with rubber additives. Mater. Struc. 42 [8], 1117-1124. https://doi. org/10.1617/s11527-008-9447-x.

12. Hashemi, M.; Shafigh, P.; Karim, M.R.B.; Atis, C.D. (2018) The effect of coarse to fine aggregate ratio on the fresh and hardened properties of roller-compacted concrete pavement. Const. Build. Mater. 169, 553-566. https://doi.org/10.1016/j. conbuildmat.2018.02.216.

13. Carlson, R.W. (1938) Drying shrinkage of concrete as affected by many factors. American Soc Testing \& Materials Proc. 38 [2], 419-437.

14. Rao, G.A. (2001) Long-term drying shrinkage of mortarinfluence of silica fume and size of fine aggregate. Cem. Concr. Res. 31 [2], 171-175. https://doi.org/10.1016/S00088846(00)00347-1.

15. Pickett, G. (1956) Effect of aggregate on shrinkage of concrete and a hypothesis concerning shrinkage. J. Proceed. 52 [1] 581-590. https://doi.org/10.14359/11617.

16. Neville, A.M. (1995) Properties of concrete, forth Edition. By AM Neville.

17. Kosmatka, S.H.; Wilson, M.L. (2016) Portland Cement Association; 16 th edition.

18. ASTM C1435 / C1435M-14 (2014) Standard practice for molding roller-compacted concrete in cylinder molds using a vibrating hammer. Annual book of ASTM standards. Philadelphia (PA, USA): American Society for Testing and Materials. https://doi.org/10.1520/c1435 c1435m-14.

19. ACI 211.3R-02 (2002) Guide for selecting proportions for no-slump concrete.

20. ASTM C157 / C157M-17 (2017) Standard test method for length change of hardened hydraulic-cement mortar and concrete. ASTM International, West Conshohocken, PA. http:// doi.org/10.1520/C0157 C0157M-17.

21. ASTM C39 / C39M-20 (2020) Standard test method for compressive strength of cylindrical concrete specimens, ASTM International, West Conshohocken, PA. http://doi. org/10.1520/C0039 C0039M-20

22. ASTM C496 / C496M-17 (2017) Standard test method for splitting tensile strength of cylindrical concrete specimens. ASTM International, West Conshohocken, PA. http://doi. org/10.1520/C0496 C0496M-17.

23. ASTM C78 / C78M-18 (2010) Standard test method for flexural strength of concrete (using simple beam with thirdpoint loading). ASTM International, West Conshohocken, PA. http://doi.org/10.1520/C0078_C0078M-18.

24. ASTM C1170/C1170M-20 (2010) Standard test method for determining consistency and density of roller-compacted concrete using a vibrating table. ASTM International, West Conshohocken, PA. http://doi.org/10.1520/C1170 C1170M-20.

25. Yerramala, A.; Babu, K.G. (2011) Transport properties of high-volume fly ash roller compacted concrete. Cem. Conc. Comp. 33 [10], 1057-1062. https://doi.org/10.1016/j.cemconcomp.2011.07.010.

26. Hashemi, M.; Shafigh, P.; Abbasi, M.; Asadi, I. (2019) The effect of using low fines content sand on the fresh and hardened properties of roller-compacted concrete pavement. Case Stud. Const. Mater. 11, e00230. https://doi.org/10.1016/j. cscm.2019.e00230.

27. Vahedifard, F.; Nili, M.; Meehan, C.L. (2010) Assessing the effects of supplementary cementitious materials on the performance of low-cement roller compacted concrete pavement. Const. Build. Mater. 24 [12], 2528-2535. https://doi. org/10.1016/j.conbuildmat.2010.06.003.

28. Neville, A.M.; Brooks, J.J. (2008) Concrete Technology, Malaysia: Prentice Hall.

29. Calverley, M.A.A. (1977) The design of British airports authority pavements. International Conference on Concrete $\mathrm{Pa}$ vement Design. https://trid.trb.org/view/717615.

30. Troxell, G. E. (1958) Log-time creep and shrinkage tests of plain and reinforced concrete. In ASTM. 58, 1101-1120.

31. Zhang, J.; Han, Y.D.; Gao, Y. (2014) Effects of water-binder ratio and coarse aggregate content on interior humidity, autogenous shrinkage, and drying shrinkage of concrete. Mater. 
Civil Engin. 26 [1], 184-189. https://doi.org/10.1061/(ASCE) MT.1943-5533.0000799.

32. Adam, I.; Sakata, K.; Ayano, T. (2001) Influence of coarse aggregate on the shrinkage of normal and high-strength concretes. J. Facult. Environ. Sci. Technol. Okayama Univ. 6 [1], 41-45. http://doi.org/10.18926/fest/11529.

33. Mehta, P. K.; Monteiro, P. J. (2017) Concrete microstructure, properties, and materials.

34. Neville, A.M. (1995) Properties of concrete (Vol. 4): Longman London.

35. Wongkeo, W.; Thongsanitgarn, P.; Chaipanich, A. (2012) Compressive strength and drying shrinkage of fly ash-bottom ash-silica fume multi-blended cement mortars. Mater. Des. (1980-2015). 36, 655-662. https://doi.org/10.1016/j. matdes.2011.11.043.

36. Bogas, J.A.; Nogueira, R.; Almeida, N.G. (2014) Influence of mineral additions and different compositional parameters on the shrinkage of structural expanded clay lightweight con- crete. Mater. Des. (1980-2015). 56, 1039-1048. https://doi. org/10.1016/j.matdes.2013.12.013.

37. Aslam, M.; Shafigh, P.; Jumaat, M.Z. (2016) Drying shrinkage behaviour of structural lightweight aggregate concrete containing blended oil palm bio-products Clean. Prod. 127, 183-194. https://doi.org/10.1016/j.jclepro.2016.03.165.

38. Kovler, K.; Jensen, O.M. (2007) Internal curing of concrete. RILEM publications SARL.

39. Basma, A.A.; Jawad, Y.A. (1995) Probability model for the drying shrinkage of concrete. Mater. 92 [3], 246-251. https:// doi.org/10.14359/1116.

40. Siegel, J.A.; Mirakovits, J.A.; Hudson, B. (2013) Concrete mix design, quality control and specification. CRC Press. https://doi.org/10.1201/b15624.

41. Videla, C.; Carreira, D.J.; Garner, N. (2008) Guide for modeling and calculating shrinkage and creep in hardened concrete. ACI report, 209. 